\title{
ANTIOXIDANT EFFECT OF ARRABIDEAE CHICA (CRAJIRU) EXTRACT ON OXIDATIVE STRESS IN DIABETIC RATS
}

\author{
EFEITO ANTIOXIDANTE DO EXTRATO DE ARRABIDEAE CHICA \\ (CRAJIRU) NO ESTRESSE OXIDATIVO EM RATOS DIABÉTICOS
}

Paula Perlles Gomes Bandeira e Sousa ${ }^{1}$, Ítalo Medeiros Azevedo ${ }^{2}$, Aldo Cunha Medeiros ${ }^{3}$

1. Graduate student, Medical School, Federal University of Rio Grande do Norte (UFRN), Natal-RN, Brazil

2. PhD, Statistician, Department of Surgery, UFRN, Natal- RN, Brazil.

3. PhD, Full Professor, Chairman, Nucleus of Experimental Surgery, UFRN, Natal, RN, Brazil.

Study performed at Department of Surgery, Federal University of Rio Grande do Norte (UFRN), Brazil.

Financial support: CNPq, Grant:311625/2018/5.

Conflicts of interest: None.

Address for correspondence: Department of Surgery, Federal University of do Rio Grande do Norte, Ave. Nilo Peçanha 620, Natal, RN, Brazil.

E-mail: cirurgex.ufrn@gmail.com.

Submitted: nov 04; accepted after revision, dec 27, 2021.

\section{ABSTRACT}

Objective: This study aimed to investigate the effects of the antioxidant potential of Arrabideae chica (crajiru) extract on oxidative stress in diabetic rats. Methods: Adult Wistar rats (Rattus norvegicus), weighing $238 \pm 12 \mathrm{~g}$ were divided into three groups of six rats each: $\mathrm{CN}$ normal untreated control; $\mathrm{DIAB}+\mathrm{NS}$ diabetic rats treated with normal saline; and diabetic rats treated with crajiru extract, DIAB+CR. The $C N$ and DIAB+NS groups (control groups) received normal saline solution (NS) orally (gavage); rats in the $\mathrm{DIAB}+\mathrm{CR}$ group received crajiru extract $(300 \mathrm{mg} / \mathrm{kg}$ ) once a day by gavage for 6 weeks. Measurements of urea and creatinine in serum, and kidney tissue catalase (CAT), superoxide dismutase (SOD), and glutathione peroxidase (GPx) were performed. The variables were assessed using the Tukey test, significance $p<0.05$. Results: All animals survived the experiments. In the $\mathrm{CN}$ group, compared with the DIAB+NS group, there was significant difference between the levels of glycemia on the second day of dosing and on the 10th day $(p<0.05)$. No difference was observed on glycemia comparing the $2^{\text {th }}$ and $10^{\text {th }}$ day on the rats of group $C+N S(p>0.05)$. Diabetic animals from DIAB $+C R$ group had a significant reduction in glycemia on 10th day of treatment, comparing the 2 nd day $(p<0.05)$. There was a significant reduction in glycemia in the DIAB+CR group, comparing with the $D I A B+N S$ group $(p<0.05)$. There was an increase in urea and creatinine levels in rats $D I A B+S N$ when compared to controls, $C+S N(p<0.001)$. Rats from 
Antioxidant effect of arrabideae chica (crajiru) extract on oxidative stress in diabetic rats Sousa PPGB; Azevedo IM; Medeiros AC

the $D I A B+C R$ group had a significant reduction in urea and creatinine, compared to the $D I A B+N S$ group $(p<0.001)$. There were no significant differences in urea and creatinine comparing the $\mathrm{C}+\mathrm{NS}$ and $\mathrm{DIAB}+\mathrm{CR}$ groups. The rats from the DIAB+NS group had significantly lower levels of CAT, GSH-px and SOD when compared to the normal control rats $(p<0.001)$. In animals from the $D I A B+S N$ group, the levels of these antioxidant enzymes were significantly reduced $(p<0.001)$. The treatment of diabetics with crajiru extract caused a significant increase $(p<0.001)$ in the levels of CAT, GSH-px and SOD, when compared to rats in the BIAB+SN group. Conclusion: The data of the present study confirms that the crajiru extract positively influenced the control of hyperglycemia in diabetic rats. More research is needed to provide a better understanding of the mechanisms of diabetes treatment using crajiru extract and its flavonoids.

Keywords: Diabetes; Rats; Arrabideae chica; Extract; Oxidative stress; Treatment.

\section{RESUMO}

Objetivo: Este estudo teve como objetivo investigar os efeitos do potencial antioxidante do extrato de Arrabideae chica (crajiru) sobre o estresse oxidativo em ratos diabéticos. Métodos: Ratos Wistar adultos (Rattus norvegicus), pesando $238 \pm 12 \mathrm{~g}$, foram divididos em três grupos de seis ratos cada. Grupo $\mathrm{CN}$ controle normal não tratado; Ratos diabéticos tratados com salina normal $(D I A B+S N)$; e ratos diabéticos tratados com extrato de crajiru (DIAB+CR). Diabetes induzida com estreptozotocina. Salina e extrato de crajiru foram injetados por via oral (gavagem); o extrato de crajiru (300 mg/kg) foi usado uma vez ao dia por gavagem por 6 semanas. Foram realizadas medições de uréia e creatinina séricas, e as enzimas antioxidantes catalase (CAT), superóxido dismutase (SOD) e glutationa peroxidase (GPx) no tecido renal dos animais. As variáveis foram avaliadas pelo teste de Tukey, significância $p<0,05$. Resultados: Todos os animais sobreviveram aos experimentos. A glicemia foi significativamente mais baixa no grupo $\mathrm{CN}$, em comparação com o grupo DIAB+NS, tanto no segundo quanto no 10 ำ dia pós indução do diabetes $(p<0,05)$. Não foi observada diferença na glicemia comparando o 2 e o 10 - dia nos ratos do grupo $C+N S(p>0,05)$. Animais diabéticos tratados com extrato de crajiru (DIAB+CR), tiveram redução significativa da glicemia, comparando o 2 dia com o 10 dia de tratamento $(p<0,05)$. Houve redução significativa da glicemia no grupo tratado com crajiru (DIAB+CR), comparando-se o grupo DIAB+NS $(p<0,05)$. Houve aumento dos níveis de uréia e creatinina nos ratos $D I A B+S N$ quando comparados aos controles, $C+S N(p<0,001)$. Ratos diabéticos do grupo $D I A B+C R$ apresentaram redução significativa da uréia e creatinina, em comparação ao grupo DIAB+NS $(p<0,001)$. Não houve diferenças significativas na uréia e creatinina entre os grupos C+NS e DIAB+CR. Os ratos do grupo DIAB+NS apresentaram níveis significativamente mais baixos de CAT, GSH-px e SOD quando comparados aos ratos controle normais - $C N(p<0,001)$. $O$ tratamento de diabéticos com extrato de crajiru causou aumento significativo $(p<0,001)$ 
Antioxidant effect of arrabideae chica (crajiru) extract on oxidative stress in diabetic rats Sousa PPGB; Azevedo IM; Medeiros AC

nos níveis de CAT, GSH-px e SOD, quando comparados aos ratos do grupo BIAB+SN. Conclusão: Os dados do presente estudo confirmam que a o extrato de crajiru influenciou positivamente no controle da hiperglicemia em ratos diabéticos. Mais pesquisas são necessárias para fornecer uma melhor compreensão dos mecanismos de tratamento do diabetes usando extrato de crajiru e seus flavonóides.

Descritores: Diabetes; Ratos; Arrabideae chica; Extrato; Estresse oxidativo; Tratamento.

\section{INTRODUCTION}

Diabetes mellitus (DM) is one of the epidemic challenging public health problems throughout the world ${ }^{1}$. The prevalence rate of diabetes is increasing exponentially and the World Health Organization predicts that by the year 2030, diabetes is expected to be the seventh leading cause of death worldwide ${ }^{2,3}$. DM is a metabolic disorder characterized by the elevation of blood glucose due to the defects in insulin action, secretion or both (insulin is insuficient or ineficient) ${ }^{4}$. Type 1, type 2 , and gestational diabetes are the three main types of diabetes targeting children, adults, and pregnant women, respectively ${ }^{5}$.

The factors such as obesity, urbanization, genetic mutations, and a lack of physical activities contribute to the pathogenesis of diabetes ${ }^{6}$. The symptoms and signs of diabetes include polyuria (frequent urination), polyphagia (increased hunger), polydipsia (increased thirst), weight loss, and unconsciousness ${ }^{7}$. Diabetes could lead to deleterious complications like nephropathy, atherosclerosis, and cardiac dysfunction and target major organs in the body such as heart, nerves, kidneys, eyes, and blood vessels ${ }^{8}$.

Oxidative stress is increased in DM, and there is often a decrease in the body's stores of ascorbic acid, which is an important dietary-derived antioxidant. Antioxidant supplementation has been suggested as a potentially beneficial adjuvant therapy ${ }^{9-11}$. A high intake of antioxidants in the diet can decrease oxidative stress and thus lower the risk of oxidative stress-related illnesses such as DM. In line with this, a higher intake of certain nutrients with antioxidant properties has been associated with a lower risk of $\mathrm{DM}^{12,13}$. Flavonoids exhibit several beneficial activities, including antibacterial, antidiabetic, antiviral, anti-inflammatory, antioxidant, anticarcinogenic, antiallergic, hepatoprotective, vasodilatory and antithrombotic activities. Some researches have focused on its antioxidant potential, due to its ability to reduce the formation of free radicals and eliminate them, leading to a therapeutic possibility of being used against diseases mediated by free radicals ${ }^{14-16}$.

There is a growing interest in natural antioxidants present in medicinal and dietary plants that can help to mitigate oxidative damage ${ }^{17}$. Arrabidaea chica (crajiru) is is widely distributed from southern Mexico to central Brazil, mainly in the Amazon region. It has been used as an anti-inflammatory and astringent agent, as well as a 
Antioxidant effect of arrabideae chica (crajiru) extract on oxidative stress in diabetic rats Sousa PPGB; Azevedo IM; Medeiros AC

remedy for intestinal cramps, diarrhea, leukorrhea, diabetes, anemia, and leukemia. This plant is a source of anthocyanins, flavonoids, tannins and phytosterols ${ }^{18-22}$. A study by Siraichi et a ${ }^{23}$ concluded that $A$. chica extract has significant antioxidant activity. This higher activity can be attributed to the presence of a mixture of compounds in the plant extract (isocutellarein, 6-hydroxyluteolin, hispidulin, scutellarein, luteolin and apigenin $)^{23}$.

Based on this knowledge, this study aimed to investigate the effects of the antioxidant potential of $A$. chica extract (crajiru) on oxidative stress in diabetic rats.

\section{METHODS}

\section{Animals}

Eighteen adult Wistar rats (Rattus norvegicus), weighing $238 \pm 12 \mathrm{~g}$, from the vivarium of the Centro de Ciências da Saúde-UFRN were used. During the acclimatization period, the animals were kept for 7 days before the beginning of the study, at the Experimental Surgery Center, where the study was carried out. All animals were housed in polypropylene cages, in a climate-controlled environment $\left(22^{\circ} \mathrm{C}\right), 12$-hour light-dark cycle and ad libitum access to water and food for laboratory rats (Prevence ${ }^{\circledR}$ ). The protocol was in accordance with the principles of Law 11.794/08 (CONCEA) and was approved by the Ethics Committee on the Use of Animals/HUOL (Protocol no 02/2020).

\section{Diabetes induction by streptozotocin}

A single $45 \mathrm{mg} / \mathrm{kg}$ body weight dose of freshly prepared streptozotocin (STZ) (STZ, S0130, Sigma-Aldrich) in $0.1 \mathrm{~mol} / \mathrm{L}$ citrate buffer $(\mathrm{pH} 4.5)$ was injected intraperitoneally to the induction of diabetes. After two days of STZ treatment, diabetes was confirmed by assessing the blood glucose of blood drawn from the tail vein of overnight fasted rats. Dosing was performed using Accu-Check, Roche Diagnostics, Germany. Rats with blood glucose levels of $250 \mathrm{mg} / \mathrm{dL}$ or more were considered diabetic and were included in the study.

\section{Experimental design}

Eighteen rats were randomly allocated into three groups of six rats each: Untreated control normal $\mathrm{CN}$; diabetic rats $(\mathrm{DIAB}+\mathrm{NS})$ and diabetic rats treated with crajiru, (DIAB+CR). The $C N$ and $D I A B+N S$ groups (control groups) received normal saline solution (NS) orally, while the rats of the $D I A B+C R$ experimental group received crajiru extract at a dose of ( $300 \mathrm{mg} / \mathrm{kg}$ ) once a day. $0.9 \%$ normal saline was used as a diluent to rebuild the extract, which was administered by gavage for 6 weeks. Crajiru dose (300 $\mathrm{mg} / \mathrm{kg}$ ) was based on the literature and on our preliminary investigation ${ }^{24}$. 
Antioxidant effect of arrabideae chica (crajiru) extract on oxidative stress in diabetic rats Sousa PPGB; Azevedo IM; Medeiros AC

\section{Preparation of A. chica extract (Crajiru)}

The alcoholic extract was prepared by maceration of $200 \mathrm{~g}$ of dried A. chica leaves. Ethanol at a ratio of 1:3 was added to the percolation process at room temperature. The material was filtered and concentrated on a rotary evaporator at a temperature of $60^{\circ} \mathrm{C}$. The extract was weighed and diluted, and an alcoholic extract at a concentration of $10 \%$ was obtained. This final extract was stored at $4^{\circ} \mathrm{C}$ until dosages.

At the end of treatment ( 6 weeks), rats were fasted overnight and intraperitoneally anesthetized the following morning with an injection of ketamine (70 $\mathrm{mg} / \mathrm{kg}$ ) + xylazine $7 \mathrm{mg} / \mathrm{kg}$. Blood samples were obtained through intracardiac puncture. Whole kidneys were quickly excised from each rat, washed in buffered saline, and used for measurements of oxidative stress markers.

\section{Biochemical analysis}

Blood samples collected by cardiac puncture were centrifuged at $3000 \mathrm{~g}$ for 10 $\min$ at $4{ }^{\circ} \mathrm{C}$ to obtain serum and then stored at $-20^{\circ} \mathrm{C}$. Urea and creatinine were measured in an autoanalyzer (Konelab, Software Version, 60i, Finland).

\section{Examination of antioxidant enzymatic parameters}

One kidney homogenate supernatants were used to examine the enzymatic antioxidant parameters catalase (CAT), superoxide dismutase (SOD), and glutathione peroxidase (GPx), using colorimetric assay kits according to the manufacturer's instructions. (ABCAM, Cambridge, MA, USA).

\section{Statistical analysis}

To test the hypothesis of difference between groups, we used: Analysis of Variance (ANOVA), followed by Tukey's multiple comparison test, with a significance level of 5\%. The statistical package BioEstat 5.0, Belém, PA, Brazil was used.

\section{RESULTS}

\section{Evolution of glycemia with treatments}

In Table 1 it can be observed that in the control group, compared with the diabetes group treated with normal saline, there was significant difference between the levels of glycemia on the second day of dosing and on the 10th day $(p<0.05)$. Nevertheless, no difference was observed on glycemia comparing the $2^{\text {th }}$ and $10^{\text {th }}$ day on the rats of group $C+N S$ ( $p>0.05$ ). When the diabetic animals were treated with crajiru extract ( $D I A B+C R$ ). There was a significant reduction in glycemia, comparing the 2 nd day with the 10th day of treatment $(p<0.05)$. There was a significant reduction in glycemia in the group treated with crajiru, comparing the DIAB+NS and DIAB+CR groups, on the second and tenth day after diabetes induction $(p<0.05)$. Data summarized in table 1. 
Antioxidant effect of arrabideae chica (crajiru) extract on oxidative stress in diabetic rats Sousa PPGB; Azevedo IM; Medeiros AC

Table 1 - Measurement of blood glucose in the $2^{\text {nd }}$ day and $10^{\text {th }}$ day after STZ injection in rats of the study groups.

\begin{tabular}{|c|c|c|}
\hline \multirow{2}{*}{ Groups } & \multicolumn{2}{|c|}{ Glycemia (mg/dL) } \\
\hline & $2^{\text {nd }}$ DAY & $10^{\text {th }}$ DAY \\
\hline $\mathrm{C}+\mathrm{NS}$ & $138 \pm 12.3^{a}$ & $140.3 \pm 9.6^{a}$ \\
\hline $\mathrm{DIAB}+\mathrm{NS}$ & $282.2 \pm 18.4^{a}$ & $278.5 \pm 15.9^{a}$ \\
\hline $\mathrm{DIAB}+\mathrm{CR}$ & $205.3 \pm 13.2^{\mathrm{a}}$ & $184.8 \pm 10.4^{\mathrm{a}}$ \\
\hline
\end{tabular}

C, control; CR, Crajiru extract; DIAB, diabetes; NS, normal saline. Measures followed of the same letter in the same line differ significantly ( $p<0.05$, Tukey test).

There was an increase in urea and creatinine levels in diabetic rats treated with normal saline $(D I A B+S N)$ when compared to control rats treated with normal saline $(C+S N)$. Statistically, the difference was significant $(p<0.001)$. When diabetic rats were treated with crajiru extract $(D I A B+C R)$, there was a significant reduction in serum levels of urea and creatinine, compared to the DIAB+NS group $(p<0.001)$. No significant differences were observed comparing the urea and creatinine levels of the $\mathrm{C}+\mathrm{NS}$ and DIAB+CR groups. Data summarized in table 2.

Table 2 - Results of renal function tests comparing groups and study.

\begin{tabular}{|c|c|c|c|c|}
\hline \multirow[b]{2}{*}{ Variables } & \multicolumn{4}{|c|}{ Groups } \\
\hline & Control C+NS & DIAB+NS & DIAB+CR & p-value ${ }^{1}$ \\
\hline Urea mg/dl) & $28,2 \pm 3,1^{a}$ & $49,5 \pm 2,8^{a}$ & $31,5 \pm 2,7^{a}$ & $<0,001$ \\
\hline Creatinine $(\mathrm{mg} / \mathrm{dl})$ & $0,8 \pm 0,2^{\mathrm{a}}$ & $2,4 \pm 0,4^{a}$ & $0,9 \pm 0,2^{a}$ & $<0,001$ \\
\hline
\end{tabular}

C, control; CR, Crajiru extract; DIAB, diabetes; NS, normal saline. Measures followed of the same letter in the same line differ significantly $(p<0.05$, Tukey test).

Table 3 - Results of statistical analysis of antioxidant enzymes in renal tissue.

\begin{tabular}{|l|c|c|c|c}
\multicolumn{1}{c}{ Variables } & \multicolumn{3}{c}{ Groups } \\
& Control C+NS & DIAB+NS & DIAB+CR & p-value \\
\hline CAT $(\mu \mathrm{mol} / \mathrm{mg})$ & $129,2 \pm 11,4^{\mathrm{a}}$ & $49,5 \pm 2,2^{\mathrm{a}}$ & $80,4 \pm 5,7^{\mathrm{a}}$ & $<0,001$ \\
\hline $\mathrm{GSH}-\mathrm{px}(\mu \mathrm{mol} / \mathrm{mg})$ & $80 \pm 3,7^{\mathrm{a}}$ & $34,6 \pm 2,3^{\mathrm{a}}$ & $62,5 \pm 4,2^{\mathrm{a}}$ & $<0,001$ \\
\hline $\mathrm{SOD}(\mu \mathrm{mol} / \mathrm{mg})$ & $26,8 \pm 2,5^{\mathrm{a}}$ & $9,4 \pm 0,7^{\mathrm{a}}$ & $21,1 \pm 1,7^{\mathrm{a}}$ & $<0,001$ \\
\hline
\end{tabular}

C, control; CR, Crajiru extract; DIAB, diabetes; NS, normal saline. CAT, catalase; SOD superóxido dismutase; GPx, glutationa peroxidase. Measures followed of the same letter in the same line differ significantly $(p<0.05)$, Tukey test. 
Antioxidant effect of arrabideae chica (crajiru) extract on oxidative stress in diabetic rats Sousa PPGB; Azevedo IM; Medeiros AC

The rats in the DIAB+NS group had significantly lower levels of CAT, GSH-px and SOD when compared to the normal control rats $(p<0.001)$. In diabetic animals treated with normal saline (DIAB+SN) the levels of these antioxidant enzymes were significantly reduced, as shown in table $3(p<0.001)$. The treatment of diabetic animals with crajiru extract caused a significant increase $(p<0.001)$ in the levels of CAT, GSH-px and SOD, when compared with the values of rats in the $B I A B+S N$ group, which confirms the antioxidant property of the extract. Data summarized in table 3.

\section{DISCUSSION}

Arrabidaea chica leaf extract has been used by Amazonian people as an antiinflammatory and astringent agent as well as a remedy for intestinal colic, diarrhea, leucorrhea, anemia, diabetes and leukemia ${ }^{18}$. A. chica is known to be a good producer of phenolics ${ }^{18}$. Flavonoids are a class of secondary plant metabolites having diverse structures ${ }^{25}$. They are polyphenolic compounds which is very commonly found in many plants, vegetables, and flowers ${ }^{26}$. Many studies have have been done on determining the biological and pharmacological activities of flavonoids that are thought to have beneficial effects on human health. The flavonoids exhibit several beneficial activities, like anti-inflammatory, antibacterial, anticarcinogenic, antiviral, antioxidant, antiallergenic, vasodilating, hepatoprotective, antidiabetic and antithrombotic activities. Most research has been focused on their antioxidant potential, which is due to their ability to reduce free radicals and scavenge free radicals, leading to a therapeutic possibility of being used against free radical-mediated diseases ${ }^{15-17}$. There is a growing interest in natural antioxidants present in medicinal and dietary plants that might help attenuate oxidative damage ${ }^{18}$. Furthermore, currently an increasing economic interest is on line with natural resources such as herbal extracts that contain antioxidants.

The significant antioxidant activity of the extract obtained from $A$. chica against the 2 metabolites might be because of the synergistic effect of the two major flavonoids present in the extract, such as scutellarein and apigenin, with other flavonoids (such as isoscutellarein, 6-hydroxyluteolin, hispidulin, and luteolin) that are known to have antioxidant activity ${ }^{27-30}$. Study performed by Siraichi et $\mathrm{al}^{23}$ demonstrated that the extract of $A$. chica have significant antioxidant activity. The high activity could be attributed to the presence of a mixture of compounds in the plant extract (isoscutellarein, 6-hydroxyluteolin, hispidulin, scutellarein, luteolin, and apigenin). We know that the yield of metabolites from plants is small; hence, it is economical to use the crude extract instead of the isolated metabolites. In the present study the extract of $A$. chica had significant positive effect in diabetic rats, whose diabetes was induced by STZ.

Diabetes could lead to deleterious complications like nephropathy, atherosclerosis, and cardiac dysfunction and target major organs in the body such as 
Antioxidant effect of arrabideae chica (crajiru) extract on oxidative stress in diabetic rats Sousa PPGB; Azevedo IM; Medeiros AC

heart, nerves, kidneys, eyes, and blood vessels ${ }^{31,32}$. Based on this, we studied the content of antioxidant enzymes in the renal tissues.

The high mortality and morbidity rate of diabetes combined with the higher risk of bacterial or viral infections or the development of cancer is a major concern of the diseases epidemic ${ }^{33}$. While currently there is no cure, diabetes is successfully treated by managing a healthy lifestyle combined with the administration of anti-diabetic agents and hypoglycemic drugs such as sulphonylureas, thiazolidinediones, and biguanides all of which reduce blood glucose ${ }^{34}$. In riverside communities in the Amazon, and in other areas where medical care is precarious, the use of herbal remedies based on crajiru extract, or even the infusion of its leaves, can be an alternative for controlling diabetes. Nutraceuticals are natural products derived from fruits and vegetables which provide multiple health benefits ${ }^{35}$.

Scientific attention has been given over the past 20 years toward natural compounds, such as flavonoids serving as an antidiabetic agent ${ }^{36}$. Flavonoids are polyphenols which are ubiquitously found in daily consumed fruits, vegetables, nuts, cocoa, tea, grain seeds, and herbs ${ }^{37}$. They represent a large class of approximately 8000 phenolic compounds ${ }^{38}$. Flavonoids are considered as a class of biologically active secondary metabolites of plants known as pigment, where they serve antiviral, antiallergic, antibacterial and anti-inflammatory functions ${ }^{39}$. The structure of flavonoids consists of 15 carbon skeletons and two aromatic rings ( $A$ and $B$ ) connected by a threecarbon chain which is usually an oxygenated heterocyclic $C$ ring $^{40}$.

Six subclasses of flavonoids are defined: flavones; flavonols; flavanones; flavan3 -ols; isoflavones; and anthocyanosides ${ }^{41}$. Flavonoids have multiple positive health effects on metabolic disorders, such as cardiovascular disease, cancer, obesity, and diabetes ${ }^{42}$. The antidiabetic activity of flavonoids supports the regulation of carbohydrate digestion, insulin signaling, insulin secretion, glucose uptake, and adipose deposition ${ }^{43}$. As crajiru leaves are very rich in flavonoids, anthocyanins and other components, with the potential to act on diabetes, undoubtedly the data from the present work, which is one of the pioneers to demonstrate its antidiabetic effects, provides another option for control of the disease. The flavonoids target multiple molecules that are involved in the regulation of several pathways, like improving $\beta$-cell proliferation, promoting insulin secretion, reducing apoptosis, and improving hyperglycemia by regulating glucose metabolism in the liver ${ }^{44}$.

A US study on 200,000 women and men evaluated the association between dietary intake of flavonoids subclasses and type 2 diabetes, confirming that a higher consumption of anthocyanins from apples, blueberries, and pears, controls the risk of diabetes $^{45}$. It is hypothesized that the majority of flavonoids bioactivity occurs due to their hydroxyl group, $\alpha$, and $\beta$ ketones ${ }^{46}$. 
Antioxidant effect of arrabideae chica (crajiru) extract on oxidative stress in diabetic rats Sousa PPGB; Azevedo IM; Medeiros AC

A water soluble, unoxidized, unsaturated flavonoid, anthocyanin, is present abundantly in crajiru leaves. Several studies, both in animal models and cell lines, suggested that anthocyanins may have anti-diabetic activities ${ }^{43}$.

In conclusion, the data of the present study confirms that the crajiru extract positively influenced the control of hyperglycemia in diabetic rats. More research is needed to provide a better understanding of the mechanisms of diabetes treatment using crajiru extract and its flavonoids.

\section{REFERENCES}

1. Chen L, Magliano DJ, Zimmet PZ. The worldwide epidemiology of type 2 diabetes mellitus-present and future perspectives. Nat Rev Endocrinol. 2011; 8: 228-236.

2. Danaei G, Finucane MM, Lu Y, Singh GM, Cowan MJ, Paciorek CJ. Global Burden of Metabolic Risk Factors of Chronic Diseases Collaborating, G. National, regional, and global trends in fasting plasma glucose and diabetes prevalence since 1980: Systematic analysis of health examination surveys and epidemiological studies with 370 country-years and 2.7 million participants. Lancet 2011; 378: 31-40.

3. World Health Organization. Definition and Diagnosis of Diabetes Mellitus and Intermediate Hyperglycemia: Report of a WHO/IDF Consultation; World Health Organization: Geneva, Switherland, 2006; pp. 1-50.

4. Akkati S, Sam KG, Tungha G. Emergence of promising therapies in diabetes mellitus. J Clin Pharmacol. 2011; 51: 796-804.

5. Kharroubi AT, Darwish HM. Diabetes mellitus: The epidemic of the century. World J Diabetes. 2015; 6: 850-867.

6. Reyes J, Tripp-Reimer T, Parker E, Muller B, Laroche H. Factors Influencing Diabetes Self-Management Among Medically Underserved Patients with Type II Diabetes. Glob Qual Nurs Res. 2017; 4: 2333393617713097.

7. Philippe J, Raccah D. Treating type 2 diabetes: How safe are current therapeutic agents? Int J Clin Pract. 2009; 63: 321-332.

8. Chawla A, Chawla R, Jaggi S. Microvasular and macrovascular complications in diabetes mellitus: Distinct or continuum? Indian J Endocrinol Metab. 2016; 20: 546551.

9. Elisaf M. Effects of fibrates on serum metabolic parameters. Curr Med Res Opin. 2002;18(5):269-276.

10. Franke SI, Muller LL, Santos MC, et al. Vitamin C intake reduces the cytotoxicity associated with hyperglycemia in prediabetes and type 2 diabetes. BioMed Res Int. 2013;2013:896536.

11. Lam CS, Benzie IF, Choi SW, et al. Relationships among diabetic retinopathy, antioxidants, and glycemic control. Optom Vis Sci. 2011;88(2):251-256.

12. Lin Y, Sun Z. Current views on type 2 diabetes. J Endocrinol. 2010;204(1):111. 
Antioxidant effect of arrabideae chica (crajiru) extract on oxidative stress in diabetic rats Sousa PPGB; Azevedo IM; Medeiros AC

13. Montonen J, Knekt $P$, Järvinen $R$, Reunanen A. Dietary antioxidant intake and risk of type 2 diabetes. Diabetes Care. 2004;27:362-6.

14. Sluijs I, Cadier E, Beulens JWJ, van der A DL, Spijkerman AMW, van der Schouw YT. Dietary intake of carotenoids and risk of type 2 diabetes. Nutr Metab Cardiovasc Dis. 2015;25(4):37681.

15. Montoro P, Braca A, Pizza C, De Tommasi N. Structure-antioxidant activity relationships of flavonoids isolated from different plant species. Food Chemistry. 2005;92: 349-355.

16. Seyoum A, Asres K, El-Fiky FK. Structure-radical scavenging activity relationships of flavonoids. Phytochemistry 2006;67: 2058-2070.

17. Cíz M, Cízová H, Denev P, Kratchanova M, Slavov A, et al. Different methods for control and comparison of the antioxidant properties of vegetables. Food Control. 2010;21: 518-523.

18. Sharififar F, Dehghn-Nudeh G, Mirtajaldini M Major flanovoids with antioxidant activity from Teucrium polium L. Food Chemistry. 2009;112: 885-888.

19. Zorn B, García-Pineres AJ, Castro V, Murillo R, Mora G, et al. 3Desoxyanthocyanidins from Arrabidaea chica. Phytochemistry 2001;56: 831-835.

20. Devia B, Llabres G, Wouters J, Dupont L, Escribano-Bailon MT, et al. New 3Deoxyanthocyanidins from leaves of Arrabidaea chica. Phytochem Analysis 2002;13: 114-120.

21. Pauletti PM, Castro-Gamboa I, Silva DHS, Young MCM, Tomazela DM, et al. New antioxidant C-glucosylxanthones from the stems of Arrabidaea samydoides . J Nat Prod. 2003;66:1384-1387.

22. De Souza AS, Pagadigorria CLS, Ishii-Iwamoto EL, Bracht A, Cortez DAG, et al. Effects of the Arrabidaea chica extract on energy metabolism in the rat liver. Pharm Biol. 2009;47: 154-161.

23. Siraichi JTG, Felipe DF, Brambilla LZS, Gatto MJ, Terra VA, et al. Antioxidant Capacity of the Leaf Extract Obtained from Arrabidaea chica Cultivated in Southern Brazil. PLOS ONE. 2013;8(8): e72733.

24. Rocha KBF, Oliveira CN, Azevedo ÍM, Macedo R, Medeiros AC. Effect of Arrabidaea chica extract against chemically induced breast cancer in animal model. Acta Cir Bras. 2019;34(10):e201901001.

25. Martens S, Mithofer A. Flavones and flavone synthases. Phytochemistry 2005;66: 2399-2407.

26. Engida AM, Kasim NS, Tsigie YA, Ismadji S, Huynh LH, et al. Extraction, identification and quantitative HPLC analysis of flavonoids from sarang semut (Myrmecodia pendan). Industrial Crops Prod. 2013;41: 392-396.

27. Guvenc, A, Okada Y, Akkol EK, Duman H, Okuyama T, et al. Investigations of antiinflammatory, antinociceptive, antioxidant and aldose reductase inhibitory activities of phenolic compounds from Sideritis brevibracteata. Food Chem. 2010;118:686-692. 
Antioxidant effect of arrabideae chica (crajiru) extract on oxidative stress in diabetic rats

Sousa PPGB; Azevedo IM; Medeiros AC

28. Yokozawa T, Dong E, Liu ZW, Shimizu M. Antioxidative activity of flavones and flavonols in vitro. Phytother Res. 1997;11: 446-449.

29. Gu L, Weng X. Antioxidant activity and components of Salvia plebeia R.Br.-a Chinese herb. Food Chem. 2001;73: 299-305.

30. Terashima M, Kakuno Y, Kitano N, Matsuoka C, Murase M, et al. Antioxidant activity of flavonoids evaluated with myoglobin method. Plant Cell Reports 2012;31: 291298.

31. Danaei G, Finucane MM, Lu Y, et al. Global Burden of Metabolic Risk Factors of Chronic Diseases Collaborating, G. National, regional, and global trends in fasting plasma glucose and diabetes prevalence since 1980: Systematic analysis of health examination surveys and epidemiological studies with 370 country-years and 2.7 million participants. Lancet. 2011;378:31-40.

32. Chawla A, Chawla R, Jaggi S. Microvasular and macrovascular complications in diabetes mellitus: Distinct or continuum? Indian J Endocrinol Metab. 2016;20:546551.

33. Muller LM, Gorter KJ, Hak E, et al. Increased risk of infection in patients with diabetes mellitus type 1 or 2 . Ned Tijdschr Geneeskd. 2006; 150: 549-553.

34. Pareek H, Sharma S, Khajja BS, Jain K, Jain GC. Evaluation of hypoglycemic and antihyperglycemic potential of Tridax procumbens (Linn.). BMC Complement Altern Med. 2009; 9: 48-55.

35. Leonidas DD, Hayes JM, Kato A, et al. Phytogenic Polyphenols as Glycogen Phosphorylase Inhibitors: The Potential of Triterpenes and Flavonoids for Glycaemic Control in Type 2 Diabetes. Curr Med Chem. 2017; 24: 384-403.

36. Ong KC, Khoo HE, Effects of myricetin on glycemia and glycogen metabolism in diabetic rats. Life Sci. 2000; 67:1695-1705.

37. Ahmad M, Akhtar MS, Malik T, Gilani AH. Hypoglycaemic action of the flavonoid fraction of Cuminum nigrum seeds. Phytother Res. 2000;14:103-106.

38. Cushnie TP, Lamb AJ. Antimicrobial activity of flavonoids. Int J Antimicrob Agents. 2005; 26:343-356.

39. Abotaleb M, Samuel SM, Varghese E, et al. Flavonoids in Cancer and Apoptosis. Cancers (Basel) 2018;11:28-35.

40. Beecher GR. Overview of dietary flavonoids: Nomenclature, occurrence and intake. J Nutr. 2003:133:3248S-3254S.

41. Scalbert A, Williamson G. Dietary intake and bioavailability of polyphenols. J Nutr. 2000;130:2073S-2085S.

42. Middleton E, Kandaswami C Jr, Theoharides TC. The effects of plant flavonoids on mammalian cells: Implications for inflammation, heart disease, and cancer. Pharmacol Rev. 2000; 52: 673-751.

43. Vinayagam R, Xu B. Antidiabetic properties of dietary flavonoids: A cellular mechanism review. Nutr Metab. (Lond.) 2015; 12:60. 
Antioxidant effect of arrabideae chica (crajiru) extract on oxidative stress in diabetic rats Sousa PPGB; Azevedo IM; Medeiros AC

44. Graf BA, Milbury PE, Blumberg JB. Flavonols, flavones, flavanones, and human health: Epidemiological evidence. J Med Food. 2005; 8: 281-290.

45. Wedick NM, Pan A, Cassidy A, et al. Dietary flavonoid intakes and risk of type 2 diabetes in US men and women. Am J Clin Nutr. 2012;95:925-933.

46. Barone E, Calabrese V, Mancuso C. Ferulic acid and its therapeutic potential as a hormetin for age-related diseases. Biogerontology 2009;10:97-108. 